\title{
The impact of neighborhood services on land values: an estimation through the hedonic pricing model
}

\author{
Asad Aziz $\cdot$ Muhammad Mushahid Anwar $\cdot$ Muhammad Dawood
}

Published online: 27 February 2020

(C) The Author(s) 2020

\begin{abstract}
A strong need exists to increase the knowledge and recognize the values of neighborhood services. This paper makes an attempt to examine the impact of neighborhood services on land values, through analysis based on results obtained from multi linear regression analysis. This case study was done in area of dense urban settlement to check the consequence of neighborhood services through the hedonic pricing model base variables which include the structural, locational, community and neighborhood services. The regression coefficient was checked at $(p<0.05)$ level of significance for each variable. The primary data was collect through the questionnaire filling by random sampling and Punjab Urban Gazette was used for the verification of land values in study area. The results found a valuable potential on land and property values of neighborhood services through the regression analysis results express through $\mathrm{R}$ (0.926), $\mathrm{R}^{2}(0.856)$ and coefficient tables to represent the effect of each individual variable on property and land values. Every individual variable play role in defining the values of land and property based upon its
\end{abstract}

A. Aziz $(\varangle) \cdot$ M. M. Anwar · M. Dawood

Department of Geography, University of Gujrat, Gujrat, Pakistan

e-mail: asadazizpakistan@gmail.com

M. M. Anwar

e-mail: Mushahid.anwar@uog.edu.pk

M. Dawood

e-mail: muhammad.dawood@uog.edu.pk utilization such as larger the structure of a property, more the covered area, larger size of a property more the land area higher price. Similarly, for locational factor study in geography, a piece of land adjacent to the road have high land values $50-70 \%$ compare to those located at distance. Very less attention has been paid on such issues in the world due to lack of effective urban planning and research on such crucial issues. If empirical studies on such issue has been done, effective way can be obtained for urban planning.

Keywords Land values - Regression analysis . Walkability $\cdot$ Hedonic model

\section{Introduction}

Everyone desire a sustainable environment and amenities in every sphere of life in difference dimensions including proximity to neighborhoods services. Equal access to locational facilities (neighborhoods amenities/services) is one of the priorities of urban policy (Bem et al. 2016). Surrounding support facilities and community locations in geographical studies are closely associated with housing price (Liang et al. 2018). The quality and condition of houses used to measure the price but often these indicators were not published in literature world (Glumac et al. 2019). The qualities including the structure of house, neighborhoods amenities and location, meanwhile condition 
and age of house, affect the housing price but not reviews directly (Masri et al. 2016). Real estate taxation differentiates the size of built structures, developed and undeveloped land and land use which has an influence on the decisions of landowners, what to build and how to build (Beer 2010). The neighborhood services near to a house are valuable, which provide neighborhoods amenities and create a potential on social, environmental, and economical values in terms of hedonic pricing theory. These residential amenities are the basic units in urban areas (Liang et al. 2018). The potential of amenities enhanced values which will increase the value of everything including a house or a property. For individual wealth a house play a vital role in designing of economic well-being and psychological significance (Sohaimi et al. 2017). In a settlement the neighborhoods amenities such as new construction of a public spaces is valuable which will increase the price of property (Zahirovich-Herbert and Gibler 2014). The assessment of these amenities is necessary for planning and distribution of these services throughout the region. Planners and scholars in geography emphasized on housing program facilities by focusing the sociodemographics environment, but its remain unknown if these facilities are not access at walkability distance due to locational/geographical factors (Woo et al. 2019). Walkability is the extent by which a build environment is friendly for people increases the livability of cities and health benefits of residents which will attract the researchers worldwide (Wang and Yang 2019). There is no perfect method to access these amenities and very little work has been done in developed as well as in developing countries throughout the world.

The neighborhood services at walkable distance are the key role for sustainable urban development. The rapid rate of urbanization threatens the neighborhoods amenities/services in urban areas all around the world. It has been notice that neighborhood amenities increase the property values in term of profit gain and sale comparison. A house or property having more neighborhood amenities will have more values, therefore the property values are varied temporally and spatially in every region in the world. For example introducing a new transit system near to a settlement increase the land values in that particular area (Dziauddin 2019). Since the property and housing price is important aspect for economic development, therefore measuring and leveling the growth is desirable for sustainable urban development. Rapid land use expansion generated over consequences of urbanization and challenges for sustainability in the context of urban policy (Huang et al. 2015). In case of urban developmental projects, education, mobility, health and sustainability have improving impacts on society, that's why it is important the policymakers should able to foresee, how the land prices are influenced by improving these facilities (Glumac et al. 2019). In recent decades affordable housing and sustainability attainment received attention of policy makers globally (Adabre and Chan 2019).

The result concluded that property buyers prefer the location of land/house or property that is near to the road and they are willing to pay more for it. This land or property can be used for residency or commercially will provide accessibility and decrease the transportation cost associated with accessibility. The regression result provided a compressive report for further research and support for policy making and urban management to the local government.

\section{Review literature}

For study in geography difference in quality across regions is heterogeneous, since the location of property is varying from place to place, and this phenomenon was observed in this case study. Much of the attempts have been made to estimate the locational characteristics and demand of the house (Follain and Jimenez 1985). However, quality change and compositional change in house/property can affect the values of property for a given time and space, to overcome these limitations serval regression base model were used in the literature (Hansen 2006). Assessment of local area values including the neighborhood amenities, social, economic and environmental dimensions of sustainability are the key to fostering development, and such type of assessment can be done through the land price function (Nakamura 2019).

Local government face increasing pressure to define land-use policies to enhance local sustainable development, that's why development in urban planning is on priority bases for selecting, measuring and interposition of areas within the cities (Pedro et al. 2019). In the world, less attention has been paid on neighborhood services close to public places and 
settlements (Chiesura 2004). About 60\% of the population lived in cities areas by 2030 (Narducci et al. 2019). Much development has been made in cities which across the limits and create challenges for sustainable urban development (Bolunda and Hunhammar 1999). One of the most important part of informal housing is concept of housing small market right (Lai et al. 2017). The booming housing market ignore the concept of sustainability and play important role in proving the inexpensive informal house in developing countries (He et al. 2019). For urban sustainability, strategies and National land use policies should be adopted to established a healthy housing market and land values assessment $(\mathrm{Hu}$ et al. 2019). Due to rapid urbanization, the spatial pattern of urban land use has been transformed into man-made features (Kong and Nakagoshi 2006). It is important for decision making process to understand the neighborhood services and sustain the ecosystem services among the population (Narducci et al. 2019).

Accessibility to environmental/neighborhood services is a major and fundamental tool for urban planning (Gavrilidis et al. 2019). The minimum distance, transportation costs, streets networking and location of property are discussing in cases of accessibility (Belmeziti et al. 2018).

The relationship between housing and land price has been disputed, on a city level the determining factors for housing and land prices are economic fundamentals (Wen and Goodman 2013). Substantial changes happening in urban areas temporally, such as infrastructure development and urban expansion which effect the suitability of recorded data and results of previous work (Bover and Velilla 2002). Meanwhile, the Hedonic Index uses the individual property and location of a house at a time for a given frame that is used in the study. This model confirm the significance of accessibility, structural attributes and neighborhood services on shaping the real estate market of the houses ( $\mathrm{Li}$ et al. 2018). The hedonic modeling is central analytic tool for assessment of market prices of real estate (Taylor 2013). For analysis of large data set in research on property estimations and marketing, the use of Multiple Linear Regression Technique is considered as a formal way for analysis is hedonic measurements (Selim 2009). Statistically, regression is a predictive analysis technique that examine the relationship between dependent and independents variables (Gkioulekas and Papageorgiou 2019).

Raising inequality and spatial concentration has been created a considerable social concern and scholarly interest, particularly in urban areas (Wei et al. 2017). In pursuit of a sustainable management plan and establishment of urban environmental sustainability, the concerning authorities such as the local government should maintain a database related to ecological, economic and social values (Aziz et al. 2019). This database is very helpful for management, establishing the mitigation plan for strategic circumstances and natural conservations. Rapid urban land expansion not only stimulates socioeconomic development, but can lead to negative impacts on environmental quality and neighborhood services, that threaten sustainable urban development and ecological construction (Liu et al. 2019). Due to urbanization process shortage of land resources is accelerated ( $\mathrm{He}$ et al. 2017). The key role for conservation is deeply related to "if you built, you will have to maintain it". For achieving sustainable urbanization, it is critical to understand the spatiotemporal heterogeneity of housing market and formulating land/housing policies (Yuan et al. 2018).

In contrast to the theoretical foundations of Hedonic Model, this term is based upon the "Lancaster (1966)" theory of consumer demand (Forenbacher et al. 2016). According to this theory, consumer makes their decisions on utilities of property attributes which were also considered in this case study. After this in 1974 the "Rosen" was first who put the Hedonic Pricing Theory according to which property is valued by its characteristics and its total cost is equal to sum of each characteristic cost to build its infrastructure (Abidoye and Chan 2017).

The key essential for the hedonic model related to coat and benefits is evaluate the environmental quality, along determining the environmental amenities including proximity to recreational sites and aesthetic views.

However, the Hedonic Pricing Model has market base price of characteristics and services in its basic premise, along with pieces of evidence, the Hedonic Pricing Model is one of best model which is used to evaluate the environmental amenities of residential properties. The hedonic pricing for property/housing prices valuation remain an active research area despite its long history (Liao and Wang 2012), and this model 
is widely adopted by scholars and professionals for price estimation real estate (Abidoye and Chan 2017). Despite the model popularity in domain of research of real estate no work on such topic is founded in Pakistan, In most of the literature the Hedonic model treat a single geographical entity as housing market (Lavaine 2019), but this case study use the multi linear regression techniques for analysis of large hedonic variables on land values.

\section{Regression model and property values}

The regression model holds dependent variables constant and measures values of independent variables (Noor et al. 2015). Regression model indicates, how much property changes by changing in each characteristic of variables through the coefficient values of each characteristic. Therefore, this technique has many complications such as all independent variables may not have a linear relationship or may not be directionally proportional to each other due to heterogeneity effect (Ligus and Peternek 2016). It can decrease the significance of result.

Studies shows a number of other methods which were also used for such type of assessment but they have only one attribute to analyzed like the Travelling cost methods measured the willingness to pay for neighborhoods site, On the other hand hedonic model is associated with variations in every individual attribute (Kahn and Walsh 2015).

The pervious literature found that combination of GIS with regression, fully explored the neighborhood amenities, distance base land values provide the evidence in numerical formwork (Noor et al. 2015), Where GIS is technique applied for implementation of locational dataset of environmental attributes (Ligus and Peternek 2016). GIS is widely used for handling of spatial data in urban developmental projects, decision making and policies (Pedro et al. 2019). The decision based on numeric values will be more reliable which provide by hedonic measurement (Pinder 2017), that's why the hedonic model is consider as best model for property values assessment. This paper is theoretical and empirical significance to understand the neighborhood services and land values in urban area.

\section{Research methodology}

The methodology used two types of data including primary data conducted through the questionnaires filling by random sampling and secondary data which obtained through the assessment of variables statically as well the reports provided by land revenue department Government of Punjab, this data is related to the price of land per marla in study area. The questionnaires were set according the objectives to achieve the targeted result including the socio economic profile of local population and hedonic model portion which including the questions related to locational, structural, community and neighborhood variables used in hedonic model and regression analysis.

The measurement of effect of neighborhoods amenities on land or property values is very rare and literature provide a little guidance to measure this effect. Traditionally, the housing price is measured through the supply and demand comparison ratio. However, a number of studies done on such case used the Hedonic Pricing Model which use the multi linear regression techniques for the assessment of numerical data as adopted in this case study by keeping the price of house/property as dependent and hedonic variables as independent variables.

Following equation express the potential of considered model in technical terms ${ }^{1}$;

$\mathrm{P}_{\mathrm{RS}}=(\mathrm{S}, \mathrm{C}, \mathrm{L}, \mathrm{N})$

Adopted: Delmelle and Duncan (2012)

where $P_{R S}$ is the single dependent variable depended on each house/property price with other variables namely (S) used for Structural variables considered, single story, numbers of bedrooms and bathrooms, (C) used for Community attributes, (L) considered for Locational attributes included, proximity to park, market, and road, (N) considered for Neighborhood, which inculding access to school, hospital and mosque.

\footnotetext{
$\overline{1}$ Total sales value of property including the land price.
} 


\section{Mathematical expressions for the hedonic variables}

$\mathrm{P}_{\mathrm{RS}}=\sum \beta \mathrm{s} \mathrm{Xs}+\beta_{\mathrm{c}} \mathrm{X}_{\mathrm{c}}+\beta_{\mathrm{L}} \mathrm{X}_{\mathrm{L}}+\beta_{\mathrm{n}} \mathrm{X}_{\mathrm{n}}+\varepsilon$

Adopted : (Delmelle and Duncan 2012)

where $\mathrm{P}_{\mathrm{rs}}=$ Hedonic Price (Predicated), $\sum=$ Sum of all variables. $\varepsilon=$ error term, Xs $=$ Vector for structural attribute, $X_{n}=$ Vector for neighborhood attribute, $X_{c}=$ Vector for Community attribute, $X_{L=}$ Vector for locational attribute.

The previous studies proved the hedonic model products are more valued by peoples (Kakar 2017). In housing and property prices estimation the hedonic model is used for the valuation of locational factors which use the regression technique for numerical estimation of data (Selim 2009). Some methods used the locational postulates only for prices estimation (Gargallo et al. 2017), But this study assumed the constant relationship among dependent and independent variables. Below, concept diagram provide overall process adopted to complete the research plan (Fig. 1).

In regression analysis the total price of property/house is taken as single dependent variable and thirteen independent variables, multi linear regression was run through Statistical software for social sciences (SPSS) to check the influence of each variable on total price of the property. For proximity measurement ArcMap of Geographical Information System was used by which data collection points were digitized to measure the effect of proximity to roads and neighborhood services and maps of land values was made as shown in results. The location of points was collected through the mobile GPS at the time of survey into the study area. The map contains the data collection points, streets view, roads adjacent to the settlement area, location of urban park and market area. The results of case study are represented through the outcomes of regression analysis in form of model summary, ANOVA analysis taken as analysis of variance and coefficient table to check the potential of every single variable on dependent variable. The values of $\mathrm{R}^{2}$ and adjusted $\mathrm{R}^{2}$ are taken as measuring the suitability that is $0.85,0.83$ respectively and their details is given in results and discussion. However, the overall model stability of regression analysis is represented through scatterplot diagram given blow in results.

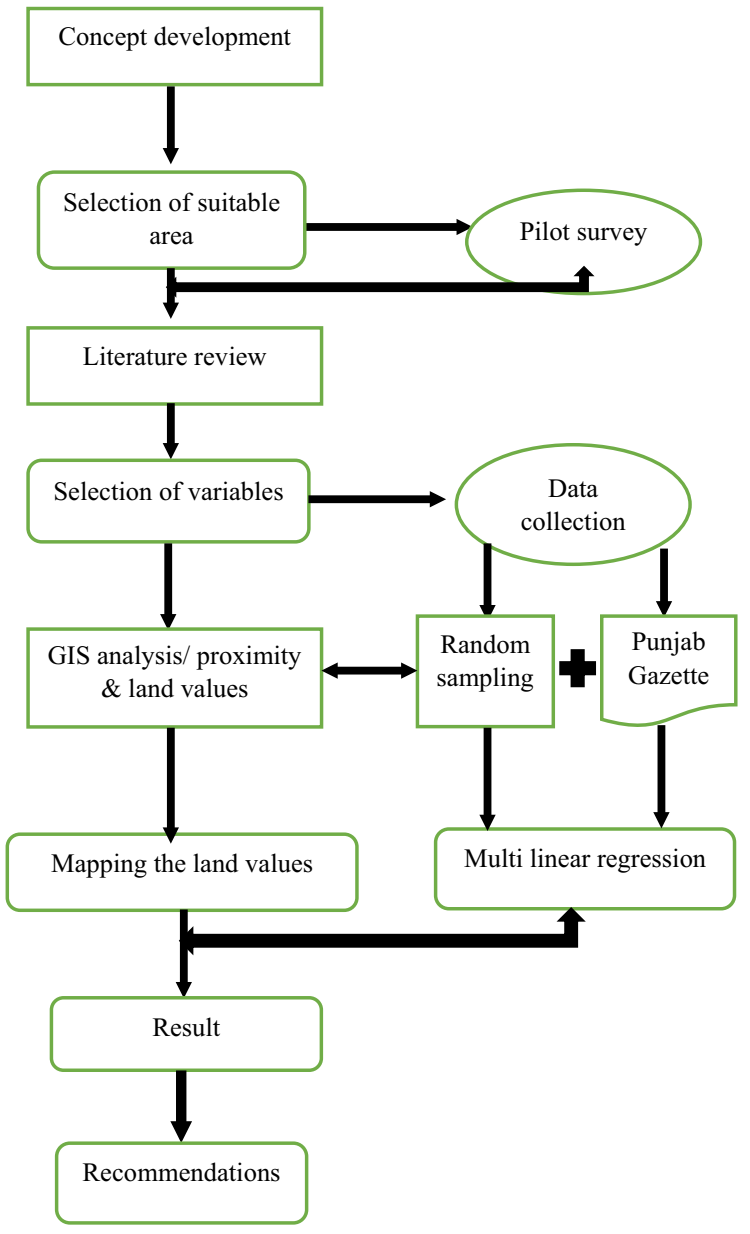

Fig. 1 Frame work of methodology Source: Author 2019

\section{Results and discussion}

The study found the positive as well as negative potential of hedonic variables on land values in study area. The result express that the potential of proximity to road is dominant factor among all neighborhood services which means a land near to road have high land values compared to those located at a distance. However, some hedonic variable also has negative results due to preference about neighborhood services and varying property characteristics due to socialeconomic status of local population and age along with time factor. The hedonic variables including land nature, hospital distance access to road and community nature in surrounding of this area respectively, are found insignificant. Due to dense streets network population have not access to major road which create hurdle for accessibility. Age of house and property is 
particular factor which decrease the value of built property with time. More the time older the structure of property reduced the values.

The study found lack of urban planning in this area that is the major case of heterogeneity in data analysis and result for this case study. This heterogeneity is related to varying characteristics of house in structure, location, distance to market, distance to hospital and age of the house. The land near to an agricultural area have least price due to non-availability of road and street networking, non-accessibility to the roads and unplanned landscape (Fig. 2).

Figure above represent the land values of Nawaz Sharif park and proximity to roads, park, open land, street and road network. The dots represent the data collection points in study area. The land adjacent to local road and near to the roads is represented in yellow dots having the highest price per marla between 350,000 to 500,000 PKR for residential and commercial areas respectively. However, the land located in agricultural areas and away from the grand trunk road has smaller price between 100,000 to 120,000 PKR per marla. Similarly, the land located within settlement represented in green and red dots having values from 150,000 to 300,000 PKR respectively as this area have assessibility to some extent to the roads and streets networking.

The Table 1 shows the result of regression analysis where the value of $\mathrm{R}(92 \%)$ showing strong correlation and model suitability. The ranges of $\mathrm{R}$ values should be $<1$. Here, the value of $\mathrm{R}$ square is 0.857 shows that above thirteen hedonic variables have $85 \%$ influence on property values which expressed as coefficient of determination. The performance of hedonic pricing model can be evaluated from the adjusted $\mathrm{R}$ square value taken as explanatory power that is 0.836 which is $83 \%$ of the variance. The $\mathrm{R}^{2}$ showing the coefficient of determination of this area that is $85 \%$ showing the accuracy of the model.

The Table 2 shows ANOVA analysis of regression results for Nawaz Sharif Park, providing overall variations in regression analysis. In above table, the value of significant is lower than value of $\mathrm{F}$, therefore overall regression result is said to be significant (Table 3).

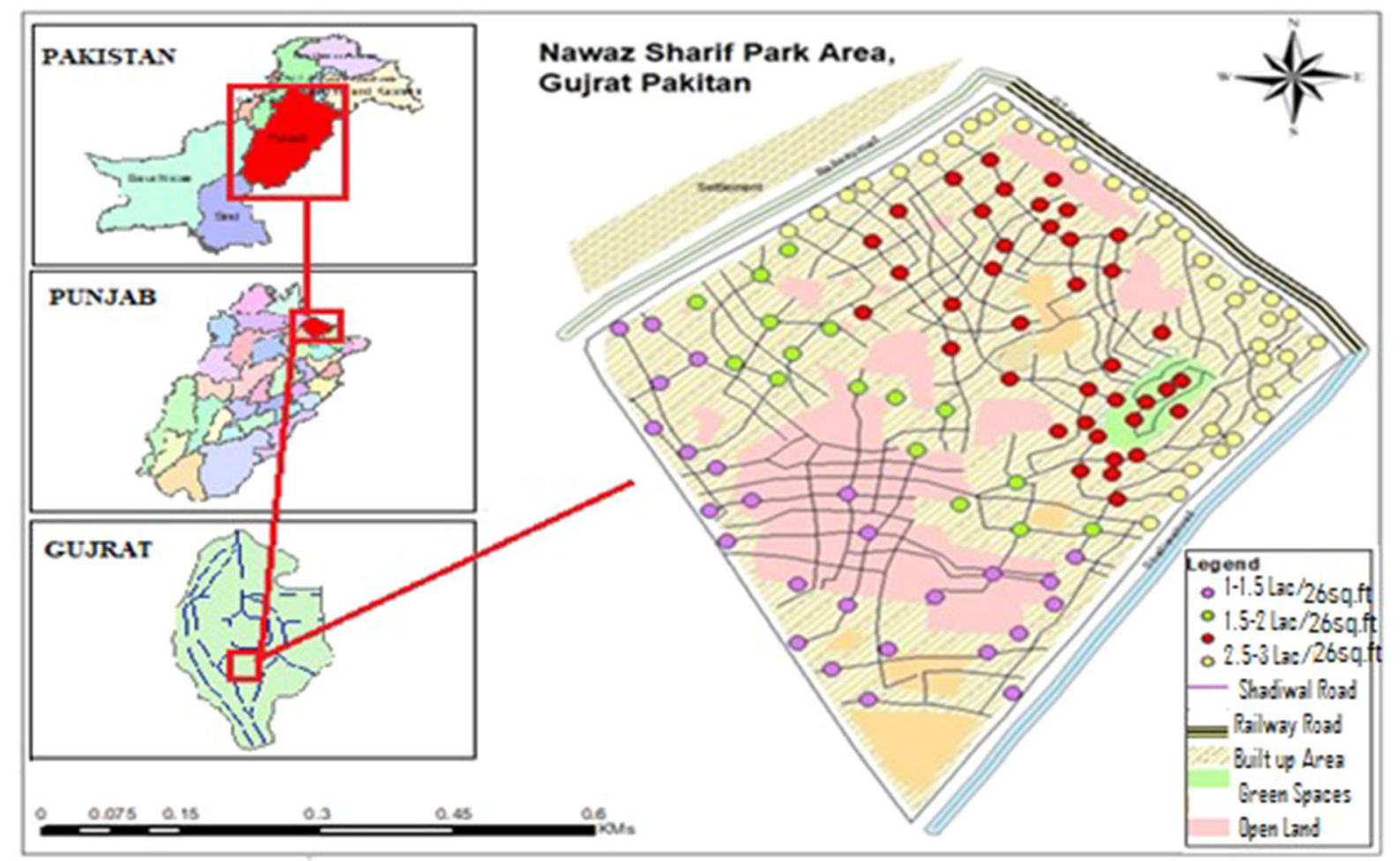

Fig. 2 Map showing the proximity and land values 
Table 1 Regression model results

\begin{tabular}{llll}
\hline $\mathrm{R}$ & $\mathrm{R}^{2}$ & Adjusted R square & $\mathrm{SE}$ of the estimate \\
\hline $0.926^{\mathrm{a}}$ & 0.857 & 0.836 & $878,789.7570^{\mathrm{a}}$
\end{tabular}

${ }^{a}$ High value for standard error due to varying price and heterogeneity in houses/property characteristics, specially location of houses and area characteristics as mixing of residential and commercial areas

The $p$ value should be less than 0.05 for that variable which effect the land/property value. In above table each variable is tested with significant value. The above table is showing the standardized coefficients of hedonic variables. The value of house and property is equal sum of all values of hedonic variables. The ' $p$ ' values of location, access, covered area, number of bath rooms, land nature, market, hospital distance and nature of social cast is $(>0.05)$ means that all of these variables are not going to effect the property values. The major cause of these negative values is the mixing of commercial and residential area and people preference and age factor. The standardized values for storeys of house (0.000), numbers of rooms (0.000) and land prices having values $(0.001)$, only determined total property values for this area.

The above figure showing the result of 13 variables used in regression variable as predicated market values at $5 \% p$ value. It is clear in the figure all of these variables are smoothly and close observed the regression line, representing the overall model fitted ratio (Fig. 3).

The below scatterplot is obtained from hedonic variables (dependent variables: total price of land/

Table 2 ANOVA analysis References: Author's calculations 2019

\begin{tabular}{llllll}
\hline Model & Sum of squares & Df & Mean square & F & Sig. \\
\hline Regression & $9.988 \mathrm{E}+14$ & 13 & $3.068 \mathrm{E}+13$ & 39.726 & $0.000^{\mathrm{b}}$ \\
Residual & $6.642 \mathrm{E}+13$ & 86 & $7.723 \mathrm{E}+11$ & $* * *$ a & $* * *$ \\
Total & $4.652 \mathrm{E}+14$ & 99 & $* * *$ & $* *$ & $* * *$ \\
\hline
\end{tabular}

$a_{* * * V a l u e s}$ are not available in ANOVA table of regression result

${ }^{\mathrm{b}}$ The beta coefficient is the degree of change in the outcome variable for every 1-unit of change in the predictor variable. The t-test assesses whether the beta coefficient is significantly different from zero. If the beta coefficient is not statistically significant (i.e., the $\mathrm{t}$-value is not significant), the variable does not significantly predict the outcome. If the beta coefficient is significant, examine the sign of the beta. If the beta coefficient is positive, the interpretation is that for every 1-unit increase in the predictor variable, the outcome variable will increase by the beta coefficient value. If the beta coefficient is negative, the interpretation is that for every 1 -unit increase in the predictor variable, the outcome variable will decrease by the beta coefficient value

Table 3 Regression model coefficients References: Author's calculations 2019

\begin{tabular}{lccc}
\hline Variables & $\beta$-beta values & T-statistics & Significant- $p$ value \\
\hline Location & -0.071 & -1.162 & 0.248 \\
Access to road & 0.019 & 0.276 & 0.783 \\
Size & 0.106 & 1.804 & 0.075 \\
Storeys & 0.302 & 4.339 & 0.000 \\
Rooms & 0.352 & 4.579 & 0.000 \\
Bath rooms & 0.098 & 1.309 & 0.194 \\
Covered area & 0.022 & 0.445 & 0.657 \\
Land price & 0.296 & 3.437 & 0.001 \\
Land nature & 0.026 & 0.548 & 0.585 \\
H-distance & 0.030 & 0.312 & 0.756 \\
M-distance & -0.110 & -1.361 & 0.177 \\
C-social & 0.003 & 0.051 & 0.959 \\
C-jobs & -0.123 & -1.884 & 0.063 \\
\hline
\end{tabular}


Normal P.P Plot of Regression Standardized Residual

Dependent Variable: What is the total price of your house/property

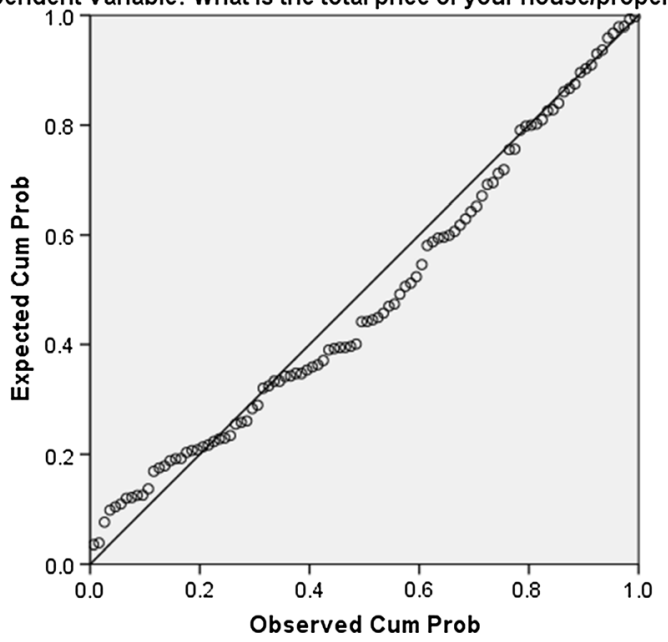

Fig. 3 Regression line showing the coefficient of hedonic variables Reference: Author 2019

property on y-axis and hedonic variables plotted on $\mathrm{x}$-axis (Fig. 4).
All expected outcomes are nearly close to each other showing regression model stability. The variation in house prices is a varying phenomenon spatially and temporally. Here price of house is related to overall price not a price of house or property at a certain period of time, a price which buyers have willing to pay along with all characteristics of the house. These movements will drive the decision for investment and purchase the house or property. Therefore, measurement and assessment is desirable for economic and financial development.

\section{Suggestion}

There is strong need of research especially in developing countries for a sustainable urban development on such types of unique issue. The local government should introduce a system and institution to register and record the data of property and owner in every corner of the city. Every city should be settled according land use model in which every house is located in such as way it has access to road, hospital,

\section{Scatterplot}

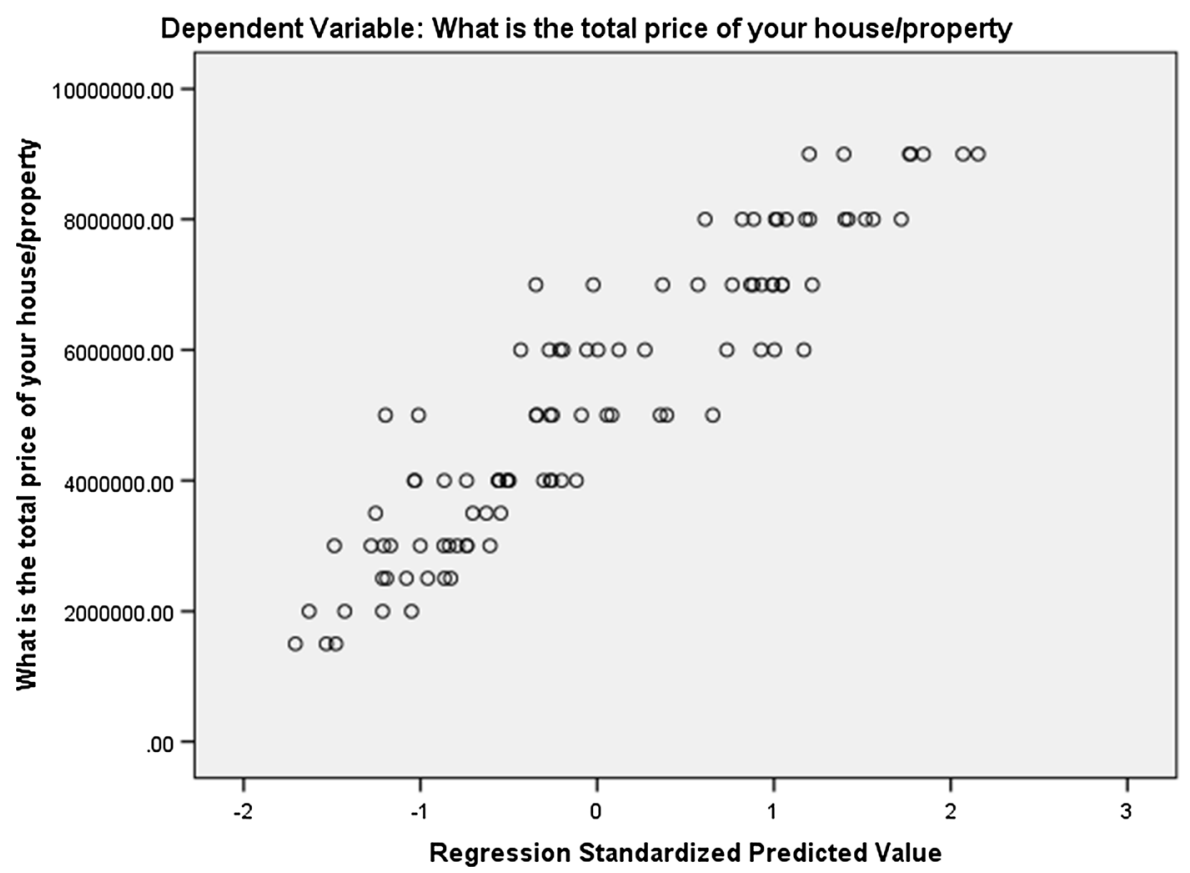

Fig. 4 Scatterplot showing the suitability of regression result 
school and market area along with other proximity measurement to neighborhoods services. The market area and hospital should be located away from each other at a distance in order to avoid the noise pollution for the patient and congested area of population for emergency response and management. Such studies should be made in education, search and government for a sustainable and developed urban planning.

Funding No source of funding is available for this paper.

\section{Compliance with ethical standards}

Conflict of interest All the authors declare that they have no conflict of interest.

Human and animal rights Yes, in survey to fill the questionnaire.

Open Access This article is licensed under a Creative Commons Attribution 4.0 International License, which permits use, sharing, adaptation, distribution and reproduction in any medium or format, as long as you give appropriate credit to the original author(s) and the source, provide a link to the Creative Commons licence, and indicate if changes were made. The images or other third party material in this article are included in the article's Creative Commons licence, unless indicated otherwise in a credit line to the material. If material is not included in the article's Creative Commons licence and your intended use is not permitted by statutory regulation or exceeds the permitted use, you will need to obtain permission directly from the copyright holder. To view a copy of this licence, visit http://creativecommons.org/licenses/by/4.0/.

\section{References}

Abidoye, R. B., \& Chan, A. P. C. (2017). Critical review of hedonic pricing model application in property price appraisal: A case of Nigeria. International Journal of Sustainable Built Environment, 6(1), 250-259. https://doi. org/10.1016/j.ijsbe.2017.02.007.

Adabre, M. A., \& Chan, A. P. C. (2019). Critical success factors (CSFs) for sustainable affordable housing. Building and Environment, 156, 203-214. https://doi.org/10.1016/j. buildenv.2019.04.030.

Aziz, A., Anwar, M. M., \& Dawood, M. (2019). Assessing land values and proximity using Hedonic model; a case study of green town Gujrat, Pakistan. Journal of Real Estate Finance and Economics. Research Paper. Geography. University of Gujrat, Gujrat, Pakistan (Submitted).

Beer, A. R. (2010). Greenspaces, green structure, and green infrastructure planning. In J. Aitkenhead-Peterson \& A. Volder (Eds.), Urban ecosystem ecology (pp. 431-448). Madison, WI: American Society of Agronomy, Crop Science Society of America, Soil Science Society of America.
Belmeziti, A., Cherqui, F., \& Kaufmann, B. (2018). Improving the multi-functionality of urban green spaces: Relations between components of green spaces and urban services. Sustainable Cities and Society, 43, 1-10. https://doi.org/ 10.1016/j.scs.2018.07.014.

Bem, A., Ucieklak-Jeż, P., \& Siedlecki, R. (2016). The spatial differentiation of the availability of health care in Polish regions. Procedia - Social and Behavioral Sciences, 220, 12-20. https://doi.org/10.1016/j.sbspro.2016.05.464.

Bolunda, P., \& Hunhammar, S. (1999). Ecosystem services in urban areas. Ecological Economics, 29(2), 293-301. https://doi.org/10.1016/S0921-8009(99)00013-0.

Bover, O., \& Velilla, P. (2002). Hedonic husing price without charactertics the case of a new multiunit housing. Paper presented at the issues in the measurement of price indices, Frankfurt am Main Germany.

Chiesura, A. (2004). The role of urban parks for the sustainable city. Landscape and Urban Planning, 68(1), 129-138. https://doi.org/10.1016/j.landurbplan.2003.08.003.

Delmelle, E., \& Duncan, M. (2012). The impact of a new light rail system on single family property values in Charlotte, North Carolina. Charlotte, NC: Environmental Systems Research Institute (ESRI).

Dziauddin, M. F. (2019). Estimating land value uplift around light rail transit stations in Greater Kuala Lumpur: An empirical study based on geographically weighted regression (GWR). Research in Transportation Economics. https://doi.org/10.1016/j.retrec.2019.01.003.

Follain, J. R., \& Jimenez, E. (1985). Estimating the demand for housing characteristics: A survey and critique. Regional Science and Urban Economics, 15(1), 77-107. https://doi. org/10.1016/0166-0462(85)90033-X.

Forenbacher, I., Perakovic, D., \& Husnjak, S. (2016). Hedonic modeling to explore the relationship of cell phone plan price and quality in Croatia. Telematics and Informatics, 33(4), 1057-1070. https://doi.org/10.1016/j.tele.2016.03. 008.

Gargallo, P., Miguel, J. A., \& Salvador, M. J. (2017). MCMC Bayesian spatial filtering for hedonic models in real estate markets. Spatial Statistics, 22, 47-67. https://doi.org/10. 1016/j.spasta.2017.07.010.

Gavrilidis, A. A., Nita, M. R., Onose, D. A., Badiu, D. L., \& Nastase, I. I. (2019). Methodological framework for urban sprawl control through sustainable planning of urban green infrastructure. Ecological Indicators, 96, 67-78. https:// doi.org/10.1016/j.ecolind.2017.10.054.

Gkioulekas, I., \& Papageorgiou, L. G. (2019). Piecewise regression analysis through information criteria using mathematical programming. Expert Systems with Applications, 121, 362-372. https://doi.org/10.1016/j.eswa. 2018.12.013.

Glumac, B., Herrera-Gomez, M., \& Licheron, J. (2019). A hedonic urban land price index. Land Use Policy, 81, 802-812. https://doi.org/10.1016/j.landusepol.2018.11. 032.

Hansen, J. (2006). Austrlian housing price: A comparsion of hedonic and repeat sales measutrements, Reverse Banl of Austrlia. Retrieved February 3, 2018, from http://www docs.fce.unsw.edu.au/fce/Research/ResearchMicrosites/ CAER/WorkshopPapers/EMG06/EMG0623.pdf. 
He, C., Han, Q., de Vries, B., Wang, X., \& Guochao, Z. (2017). Evaluation of sustainable land management in urban area: A case study of Shanghai, China. Ecological Indicators, 80, 106-113. https://doi.org/10.1016/j.ecolind.2017.05. 008.

He, S., Wang, D., Webster, C., \& Chau, K. W. (2019). Property rights with price tags? Pricing uncertainties in the production, transaction and consumption of China's small property right housing. Land Use Policy, 81, 424-433. https://doi.org/10.1016/j.landusepol.2018.10.038.

Hu, L., He, S., Han, Z., Xiao, H., Su, S., Weng, M., et al. (2019). Monitoring housing rental prices based on social media: An integrated approach of machine-learning algorithms and hedonic modeling to inform equitable housing policies. Land Use Policy, 82, 657-673. https://doi.org/10.1016/j. landusepol.2018.12.030.

Huang, Z., Wei, Y. D., He, C., \& Li, H. (2015). Urban land expansion under economic transition in China: A multilevel modeling analysis. Habitat International, 47, 69-82. https://doi.org/10.1016/j.habitatint.2015.01.007.

Kahn, M. E., \& Walsh, R. (2015). Chapter 7-Cities and the environment. In G. Duranton, J. V. Henderson, \& W. C. Strange (Eds.), Handbook Of Regional And Urban Economics (Vol. 5, pp. 405-465). Amsterdam: Elsevier.

Kakar, A. K. S. (2017). Why do users prefer the hedonic but choose the Utilitarian? Investigating user dilemma of hedonic-utilitarian choice. International Journal of Human-Computer Studies, 108, 50-61. https://doi.org/10. 1016/j.ijhcs.2017.07.003.

Kong, F., \& Nakagoshi, N. (2006). Spatial-temporal gradient analysis of urban green spaces in Jinan, China. Landscape and Urban Planning, 78(3), 147-164. https://doi.org/10. 1016/j.landurbplan.2005.07.006.

Lai, Y., Zheng, X., Choy, L. H. T., \& Wang, J. (2017). Property rights and housing prices: An empirical study of small property rights housing in Shenzhen, China. Land Use Policy, 68, 429-437. https://doi.org/10.1016/j.landusepol. 2017.08.010.

Lavaine, E. (2019). Environmental risk and differentiated housing values: Evidence from the north of France. Journal of Housing Economics, 44, 74-87. https://doi.org/10.1016/ j.jhe.2019.02.001.

Li, H., Wei, Y. D., Wu, Y., \& Tian, G. (2018). Analyzing housing prices in Shanghai with open data: Amenity, accessibility and urban structure. Cities. https://doi.org/10. 1016/j.cities.2018.11.016.

Liang, X., Liu, Y., Qiu, T., Jing, Y., \& Fang, F. (2018). The effects of locational factors on the housing prices of residential communities: The case of Ningbo, China. Habitat International, $\quad 81, \quad 1-11 . \quad$ https://doi.org/10.1016/j. habitatint.2018.09.004.

Liao, W.-C., \& Wang, X. (2012). Hedonic house prices and spatial quantile regression. Journal of Housing Economics, 21(1), 16-27. https://doi.org/10.1016/j.jhe.2011.11.001.

Ligus, M., \& Peternek, P. (2016). Measuring structural, location and environmental effects: A hedonic analysis of housing market in Wroclaw, Poland. Procedia - Social and Behavioral Sciences, 220, 251-260. https://doi.org/10. 1016/j.sbspro.2016.05.497.
Liu, Y., Song, W., \& Deng, X. (2019). Understanding the spatiotemporal variation of urban land expansion in oasis cities by integrating remote sensing and multi-dimensional DPSIR-based indicators. Ecological Indicators, 96, 23-37. https://doi.org/10.1016/j.ecolind.2018.01.029.

Masri, M. H. B., Nawawi, A. H. B., \& Sipan, I. B. (2016). Review of building, locational, neighbourhood qualities affecting house prices in Malaysia. Procedia - Social and Behavioral Sciences, 234, 452-460. https://doi.org/10. 1016/j.sbspro.2016.10.263.

Nakamura, H. (2019). Relationship among land price, entrepreneurship, the environment, economics, and social factors in the value assessment of Japanese cities. Journal of Cleaner Production, 217, 144-152. https://doi.org/10. 1016/j.jclepro.2019.01.201.

Narducci, J., Quintas-Soriano, C., Castro, A., Som-Castellano, R., \& Brandt, J. S. (2019). Implications of urban growth and farmland loss for ecosystem services in the western United States. Land Use Policy, 86, 1-11. https://doi.org/ 10.1016/j.landusepol.2019.04.029.

Noor, N. M., Asmawi, M. Z., \& Abdullah, A. (2015). Sustainable urban regeneration: GIS and hedonic pricing method in determining the value of green space in housing area. Procedia - Social and Behavioral Sciences, 170, 669-679. https://doi.org/10.1016/j.sbspro.2015.01.069.

Pedro, J., Silva, C., \& Pinheiro, M. D. (2019). Integrating GIS spatial dimension into BREEAM communities sustainability assessment to support urban planning policies, Lisbon case study. Land Use Policy, 83, 424-434. https:// doi.org/10.1016/j.landusepol.2019.02.003.

Pinder, J. P. (2017). Chapter 10-Regression. In J. P. Pinder (Ed.), Introduction to business analytics using simulation (pp. 313-369). Boston: Academic Press.

Selim, H. (2009). Determinants of house prices in Turkey: Hedonic regression versus artificial neural network. Expert Systems with Applications, 36(2), 2843-2852. https://doi. org/10.1016/j.eswa.2008.01.044.

Sohaimi, N., Abdullah, A., Shuid, S., \& Ahmad Sarkawi, A. (2017). Young professionals' housing affordability through housing preferences in Kuala Lumpur and a review on the means-end chain model. Planning Malaysia Journal, 15, 369-376.

Taylor, L. O. (2013). Hedonics. In J. F. Shogren (Ed.), Encyclopedia of energy, natural resource, and environmental economics (pp. 342-348). Waltham: Elsevier.

Wang, H., \& Yang, Y. (2019). Neighbourhood walkability: A review and bibliometric analysis. Cities, 93, 43-61. https:// doi.org/10.1016/j.cities.2019.04.015.

Wei, Y. D., Li, H., \& Yue, W. (2017). Urban land expansion and regional inequality in transitional China. Landscape and Urban Planning, 163, 17-31. https://doi.org/10.1016/j. landurbplan.2017.02.019.

Wen, H., \& Goodman, A. C. (2013). Relationship between urban land price and housing price: Evidence from 21 provincial capitals in China. Habitat International, 40, 9-17. https://doi.org/10.1016/j.habitatint.2013.01.004.

Woo, A., Yu, C.-Y., \& Lee, S. (2019). Neighborhood walkability for subsidized households: Revisiting neighborhood environments of Housing Choice Voucher and Low- 
Income Housing Tax Credit households. Cities, 89, 243-251. https://doi.org/10.1016/j.cities.2019.03.002.

Yuan, F., Wu, J., Wei, Y. D., \& Wang, L. (2018). Policy change, amenity, and spatiotemporal dynamics of housing prices in Nanjing, China. Land Use Policy, 75, 225-236. https://doi. org/10.1016/j.landusepol.2018.03.045.

Zahirovich-Herbert, V., \& Gibler, K. M. (2014). The effect of new residential construction on housing prices. Journal of
Housing Economics, 26, 1-18. https://doi.org/10.1016/j. jhe.2014.06.003.

Publisher's Note Springer Nature remains neutral with regard to jurisdictional claims in published maps and institutional affiliations. 